\title{
Variability of aerosol properties over Eastern Europe observed from ground and satellites in the period from 2003 to 2011
}

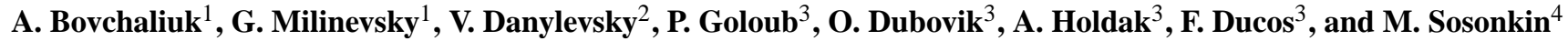 \\ ${ }^{1}$ Space Physics Laboratory, Astronomy and Space Physics Department, Kyiv National Taras Shevchenko University, 64 \\ Volodymyrska Str., 01601 Kyiv, Ukraine \\ ${ }^{2}$ Astronomical Observatory, Kyiv National Taras Shevchenko University, 3 Observatorna Str., 04053 Kyiv, Ukraine \\ ${ }^{3}$ Laboratoire d'Optique Atmosphérique, LOA - UFR de Physique - Batiment P5, Université des Sciences et Technologies de \\ Lille (Lille I), 59655 Villeneuve d'Ascq Cedex, France \\ ${ }^{4}$ Main Astronomical Observatory of the NAS of Ukraine, Laboratory of Atmospheric Optics, 27 Akademika Zabolotnogo \\ Str., 03680 Kyiv, Ukraine
}

Correspondence to: A. Bovchaliuk (bovchaliuk@gmail.com)

Received: 9 January 2013 - Published in Atmos. Chem. Phys. Discuss.: 24 January 2013

Revised: 29 May 2013 - Accepted: 10 June 2013 - Published: 11 July 2013

\begin{abstract}
The paper presents some results of the study on aerosol variability in the period from 2003 to 2011 over the Eastern Europe region, with latitude ranging from $40^{\circ} \mathrm{N}$ to $60^{\circ} \mathrm{N}$ and longitude from $20^{\circ} \mathrm{E}$ to $50^{\circ} \mathrm{E}$. The analysis was based on the POLDER/PARASOL and POLDER-2/ADEOS satellites and AERONET (AErosol RObotic NETwork) ground-based sun photometer observations. The aerosol optical thickness (AOT) of the studied area is characterized by values (referenced to $870 \mathrm{~nm}$ wavelength) ranging from 0.05 to 0.2 , except for in the period of July-August 2010 with strong forest and peat wildfires when the AOT typical values range from 0.3 to 0.5 according to both retrievals. The analysis of seasonal dynamics of aerosol loading has revealed two AOT high value peaks. The spring peak observed in AprilMay is the result of solitary transportation of Saharan dust in the atmosphere over Eastern Europe, infrequent agricultural fires, transportation of sea salt aerosols by southern winds to Ukraine and Moldova from the Black and Azov seas. The autumn peak in August-September is associated with forest and peat wildfires, considerable transportation of Saharan dust and the presence of soil dust aerosols due to harvesting activity. The maximum values of AOT are observed in May 2006 (0.1-0.15), April 2009 (0.07-0.15) and August $2010(0.2-0.5)$. Furthermore, the study has identified a distinct pattern of anthropogenic aerosols over the industrial areas, especially in central Ukraine and eastern Belarus as well as Moscow region in Russia.
\end{abstract}

The comparison of the AOT derived by standard algorithm POLDER/PARASOL with those recomputed from AERONET inversions for fine mode particles with radius $<0.3 \mu \mathrm{m}$ was performed over several AERONET sites. The correlation coefficients for the POLDER/AERONET AOT retrieval comparisons are equal: 0.78 for Moscow site, 0.76 - Minsk, 0.86 - Belsk, 0.81 - Moldova (period 2005-2009), 0.93 - Kyiv and 0.63 for Sevastopol sites (2008-2009). The deviations are explained by the spatial inhomogeneity of the surface polarization that has a stronger effect on aerosol retrieval for clear atmospheric conditions with low aerosol loading when surface impact on satellite observations is more pronounced. In addition, the preliminary analysis of the detailed aerosol properties derived by a new generation PARASOL algorithm was evaluated. The comparison of AOT and single scattering albedo retrieved from the POLDER/PARASOL observations over Kyiv with the closest AERONET retrievals within $30 \mathrm{~min}$ of satellite overpass time and with a cloudless day shows acceptable agreement of the aerosol dynamics. The correspondence of those data is observed even for extreme AOT440 value 1.14, which was caused by the forest and peat fires in August 2010. 


\section{Introduction}

Aerosols in the terrestrial atmosphere arise as particular matter entering the atmosphere from sources on the earth's surface (primary aerosols) and are being generated in the atmosphere by gas-to-particle conversion processes (secondary aerosols) (Seinfeld and Pandis, 2006). Aerosol mass in the atmosphere comprises about $10^{-9}$ of all air mass, but the role of aerosols in the radiative balance of terrestrial atmosphere on the regional and global scales can be very important, firstly because of solar radiation scattering by aerosol particles, and secondary because of aerosols interaction with water vapor and the formation of clouds (Seinfeld and Pandis, 2006; Chin et al., 2009). Moreover aerosols influence not only the radiative balance of atmosphere, but also have considerable impact on air quality. Almost at all optical wavelengths (from near UV to near IR), the coefficients of aerosol extinction, scattering and absorption are approximately on the same order as for all atmospheric gases, but aerosol content in the atmosphere and particles optical properties are much more variable both in time and space. Primary aerosol particles are produced both from natural sources, such as forest wildfires, sea spray, desert sandstorms and volcanic eruptions, and from human activities, such as industry, fossil fuel and biomass burning, deforestation, etc. (Chin et al., 2009). This is the reason why aerosol particles are diverse in size, shape and chemical composition, and depending on physical and chemical properties aerosols can cause an increase or decrease in the planet's temperature (Seinfeld and Pandis, 2006; Chin et al., 2009). Therefore, aerosols effect on the earth's energy budget is determined with large uncertainties (IPCC, 2007).

Spatial and temporal variation of aerosol physical and chemical properties and their impact on the climate are studied by using the ground-based measurements by sun photometers and lidars networks, e.g., AERONET (Holben et al., 1998), SKYNET (Takamura et al., 2004), GLOBE (Finarelli, 1998; Boersma and de Vroom, 2006), EARLINET (Amodeo et al., 2006), MPLNET (Welton et al., 2006), and satellite observations of optical radiation scattered by the earth's atmosphere and surface. The satellite techniques enable us to derive the aerosol distribution over the globe by scanning the atmosphere and surface along and across satellite ground tracks at specific overpass time. There are several data sets of global aerosol properties over land and oceans available from various satellite sensors, e.g., MODIS, MERIS, MISR, AVHRR, POLDER, TOMS and OMI, that cover rather long time spans from months to decades (King et al., 1999; Mishchenko et al., 2007; Kaufman et al., 2002). The ground-based technique also allows the continuous accumulation of data over long periods of time (years and decades) but only at specific observational locations. From data collected by both ground-based and satellite techniques, aerosol properties are estimated as the parameters of models solving the inverse problem (King et al., 1999; Dubovik et al., 2002b, 2011; Kokhanovsky and de Leeuw, 2009). The extreme complexity and variability of earth's atmospheresurface system are the main source of errors when retrieving aerosol parameters from satellite data. Therefore, the retrievals of aerosol parameters from satellite remote measurements are more complicated than those from ground-based observations, so extensive validation of satellite retrievals is required. As a rule, the data of the ground-based sun photometers network AERONET are used as references for validation (Lee et al., 2009; Li et al., 2009; Mishchenko et al., 2010; Schuster et al., 2012).

The field of interest in this work is the Eastern Europe region with latitudes from $40^{\circ} \mathrm{N}$ to $60^{\circ} \mathrm{N}$ and longitudes from $20^{\circ} \mathrm{E}$ to $50^{\circ} \mathrm{E}$. Authors of the preceding analyses (Giles et al., 2012) considered this region as a source of urbanindustrial aerosols in concordance with general aerosol types classification (Dubovik et al., 2002a). Indeed, there are many existing and potential aerosol pollution sources here: transport, intensive agriculture, heavy industry, metallurgy, as well as exploitation of open mines. Furthermore, this region is characterized by numerous forest, grassland and peat fires, and we can sometimes also consider the region as source of biomass burning aerosol (http://www.ceip.at/). For example, the forest and peat wildfires in Moscow Region in September 2002 caused increase of aerosol optical thickness (AOT) and transportation of aerosols by air masses to Moldova through Belarus and Ukraine (Aculinin et al., 2004; Eck et al., 2003). Moreover, ten cases of very high AOT values during 2001-2005 (mainly in August) were observed with UV-Raman lidar over Thessaloniki, Greece (Amiridis et al., 2009). These events were identified by authors as agricultural burning across Russia in the latitudinal belt between $45^{\circ} \mathrm{N}$ and $55^{\circ} \mathrm{N}$, as well as in Eastern Europe (Baltic countries, Belarus and Ukraine). Numerous biomass burning events affect, to a considerable degree, aerosol amounts and properties over the region of interest annually for spring, summer and autumn. Many authors note regular increase of aerosol loading to atmosphere in April-May and July-August associated with croplands, peats and forest fires (Korontzi et al., 2006; Jaroslawski and Pietruczuk, 2010; Amiridis et al., 2010; Sciare et al., 2008; Pietruczuk and Chaikovsky, 2012). Stohl et al. (2007) observed emissions from agricultural fires in the Baltic countries, Belarus, Ukraine and Russia at the end of April and beginning of May 2006 that caused the most severe air pollution episode over the recorded period at research stations in Svalbard (Lund Myhre et al., 2007). The contribution of wildfires and agricultural fires in this region to the European fine fraction aerosol optical thickness are estimated to be $20-35 \%$ in April and $28 \%$ in August through the period from 2002 to 2007 (Barnaba et al., 2011).

Considerable amounts of dust aerosols are also observed sometimes over the region, both local origination and transported from distant sources. For instance, an incidental soil dust event was observed in Europe in 23-25 March 2007. It originated in southern Ukraine (Kherson, Mykolaiv, 
Zaporizhia regions) known for its erodible lands (Birmili et al., 2008; Bessagnet et al., 2008). This soil dust plume with dominant particle size $1-5 \mu \mathrm{m}$ was transported through Ukraine, Moldova, Slovakia, Czech Republic, Austria, Poland and Germany to Belgium, North France and the UK. The Sahara is the major source of mineral dust that often spreads across the Mediterranean to Europe. Saharan dust aerosols over the northeastern Mediterranean that lies on the way for aerosol to the Eastern Europe region is well studied in Papayannis et al. (2005), Papayannis et al. (2008), Kalivitis et al. (2007), and Gerasopoulos et al. (2007). According to Israelevich et al. (2012), whose research is based on data from MODIS for the period from 2001 to 2010, the Saharan dust is transported to the Eastern Europe region mostly in autumn (August-September) and in spring (April).

In the paper we analyze and compare the results of the aerosol distribution and variability over the Eastern Europe region obtained by ground-based sun photometers and satellite data collected in 2003-2011 by POLDER-2 and POLDER-3 instrument. The paper is organized as follows. In Sect. 2, we present the analysis of aerosol characteristics and dynamics obtained by ground-based sun photometers. Section 3 gives an overview of the monthly mean AOT received from satellite POLDER/PARASOL data and describes aerosol loading in the atmosphere. In Sect. 4, we present the comparison of the POLDER/AERONET AOT retrievals over several AERONET sites. Finally, we draw conclusions and outline future works in Sect. 5.

\section{Analysis of aerosol properties using ground-based data}

In this section we analyze shortly the data obtained by ground-based network AERONET (AErosol RObotic NETwork). The network provides continuous time series data with a high temporal resolution obtained for a site of measurements during many years (Holben et al., 1998). The main instruments used by AERONET to study aerosol properties are the automatic sun tracking and sky scanning sun photometers CIMEL CE-318 (CIMEL Electronique, France; http://www.cimel.fr/). Several modifications of the CE-318 sun photometers are used for measurements of spectral AOT in spectral range $340-1650 \mathrm{~nm}$ with errors \pm 0.01 to \pm 0.02 in visible and IR and with the highest uncertainty in the UV; in addition, the Ångström exponent and precipitable water vapor thickness are determined from the AOT measurements. Also the sun photometers measure sky spectral radiance scanning along the almucantar and in the principal plane of the sun (i.e., along the sun's circle of the height). Also some of the sun photometers models can measure polarization of the sky in principal plane. The technical specifications of the sun photometers, calibration and measurement procedures, data processing and the accuracy of measurements are described in (Holben et al., 1998; Smirnov
Table 1. AERONET sites selected for analysis.

\begin{tabular}{lll}
\hline Site & Coordinates & Date of setup \\
\hline Moscow, Russia & $55.7000^{\circ} \mathrm{N}, 37.5100^{\circ} \mathrm{E}$ & August 2001 \\
Minsk, Belarus & $53.9200^{\circ} \mathrm{N}, 27.6010^{\circ} \mathrm{E}$ & July 2002 \\
Belsk, Poland & $51.8367^{\circ} \mathrm{N}, 20.7917^{\circ} \mathrm{E}$ & April 2002 \\
Kyiv, Ukraine & $50.3636^{\circ} \mathrm{N}, 30.4966^{\circ} \mathrm{E}$ & April 2008 \\
Moldova, Moldova & $47.0001^{\circ} \mathrm{N}, 28.8156^{\circ} \mathrm{E}$ & September 1999 \\
Sevastopol, Ukraine & $44.6158^{\circ} \mathrm{N}, 33.5173^{\circ} \mathrm{E}$ & May 2006 \\
\hline
\end{tabular}

et al., 2000). The aerosol particles properties, such as volume size distribution, the real and imaginary part of refractive index, spectral single scattering albedo (SSA), phase function and its asymmetry factor and some others are retrieved from sky spectral radiance and polarization measurements by inverse procedures described in Dubovik and King (2000), Dubovik et al. (2000), Dubovik et al. (2006), and Eck et al. (1999), and in technical and quality assurance documents available on the AERONET official website (http: //aeronet.gsfc.nasa.gov). For classification of aerosol types, the Ångström exponent curvature related to the aerosol size distribution can be used (Eck et al., 1999; Giles et al., 2012). According to Yoon et al. (2012) using the Ångström exponent (ÅE) and Ångström exponent difference (ÅED) can minimize the data loss in the classification process because the volume size distribution is only valid for solar zenith angle $(\mathrm{SZA})>50^{\circ}$ and SSA needs an additional criterion: AOT at $440 \mathrm{~nm}>0.4$ (Dubovik et al., 2000).

We have analyzed the cloud-screened and quality-assured data (Level 2.0) (Holben et al., 1998; Smirnov et al., 2000) obtained in the region under study. The chosen sites, coordinates and date of setup are shown in Table 1. In order to characterize aerosol pollution, the monthly average AOT and Ångström exponent over the entire observation period are given in Fig. 1. The standard deviations of monthly average values are bigger in August and September which corresponds to strong forest and peat wildfires in September 2002 (Aculinin et al., 2004; Eck et al., 1999; Amiridis et al., 2009) and August 2010 (Konovalov et al., 2011; Chubarova et al., 2012; Witte et al., 2011). It should be noted that the measurements were distributed non-uniformly through the year, e.g., in winter the number of observational days was significantly smaller than in other seasons. Detailed figures of AOT and Ångström exponent dependences on time during 2001-2011 years are presented in the Supplement.

The two peaks of aerosol amount seen in Fig. 1 show the increase in AOT which was observed in each site. The spring peak (April-May) is partially explained by agricultural fires that were started by farmers who burn their fields before a new growing season (this practice is banned in the European Union but is still widely used in Eastern Europe for crop rotation and controlling insects). Correspondingly, the values of the Ångström exponent are increased in AprilMay which could be explained by the increase in fine fraction 

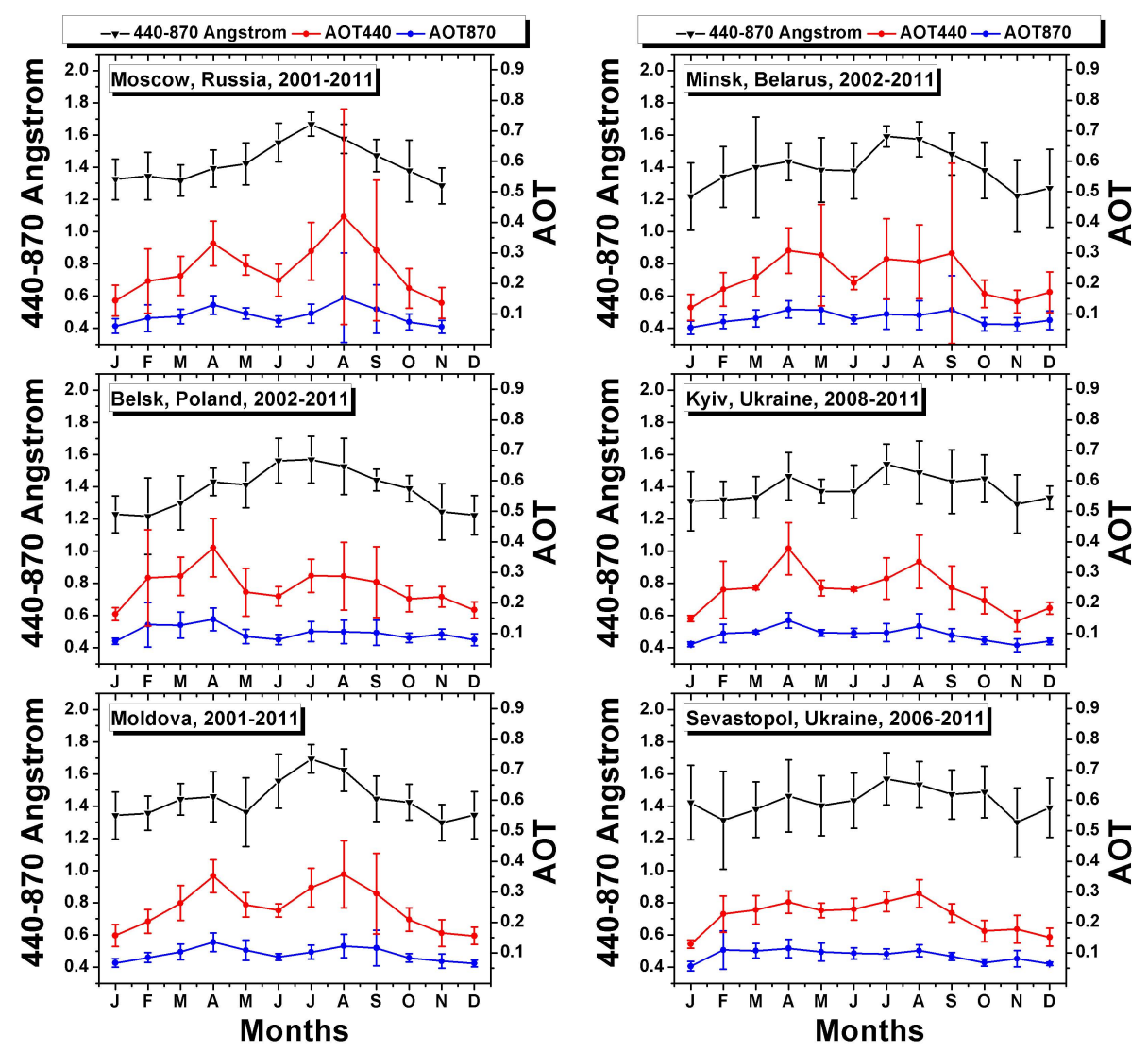

Fig. 1. Monthly average AOT at 440 (red), $870 \mathrm{~nm}$ (blue) and Ångström exponent computed from 440 to $870 \mathrm{~nm}$ (black) from Moscow, Minsk, Belsk, Kyiv, Moldova and Sevastopol sun photometers.

aerosols such as smoke particles. Moreover, Saharan dust in the atmospheric layer over Eastern Europe can also increase AOT value in spring (Israelevich et al., 2012). According to model simulations presented by Jaeglé et al. (2011), the lifetime of sea salt aerosols with particle size up to $4 \mu \mathrm{m}$ is $12-25 \mathrm{~h}$. The sea salt aerosols are transported to Ukraine and Moldova from the Black and Azov seas (Manders et al., 2010; Aan de Brugh et al., 2011; Novikova, 2009) by the southern wind in spring (see Fig. S2 in the Supplement). Therefore, monthly mean volume size distributions (Fig. 3) show the presence of $0.5-4 \mu \mathrm{m}$ particles over Sevastopol and Moldova sites in April-May. In order to confirm the presence of sea salt aerosols the follow classification have been applied based on results presented by Yoon et al. (2012). The dependence of Ångström exponent difference ( $\AA \mathrm{E}(440-$ $675 \mathrm{~nm})-\AA ̊ \mathrm{E}(675-870 \mathrm{~nm})$ ) from Ångström exponent (440$870 \mathrm{~nm}$ ) is presented in Fig. $2 \mathrm{~b}$ for the Moldova site during April-May 2003. To avoid large errors in Ångström exponent and its difference from low AOTs, only AERONET Level 2.0 data with AOT440 $>0.15$ were used in this analysis. According to classification proposed by Yoon et al. (2012) the biomass burning, industrial, sea salt and sometimes dust aerosols are presented in the atmosphere in April (446 of all measurements). However, sea salt and dust aerosols are constituted predominantly in May 2003 (629 of all measurements) over Moldova.

The AOT peak in August-September is associated with the fires in croplands, as well as forest and peat wildfires. Furthermore, harvesting causes an increase in soil dust amount in the atmosphere (Sterk and Goossens, 2007; Hinz and Funk, 2007) and the particles of $1-5 \mu \mathrm{m}$ in size can be transferred hundreds kilometers in strong surface wind weather conditions (Gross and Barring, 2003; Bessagnet et al., 2008; Ginoux et al., 2001). Also imported Saharan dust can be added to aerosol content over the region of interest (Israelevich et al., 2012). The Ångström exponent values are higher in August than in September which was observed in each site.

The maximum AOT values were revealed in July-August 2010 (see Fig. S1 in the Supplement) that correspond to wildfires in the centre of western Russia (Konovalov et al., 2011; Chubarova et al., 2012; Witte et al., 2011). Using the classification of aerosol types proposed by Yoon et al. (2012), the biomass burning and urban aerosols are constituted in the atmosphere in July (788 of all measurements) and August (232 of all measurements) over Moscow (Fig. 2d). The increase in AOT values is observed in all considered stations mainly 
due to transportation of aerosols from wildfires region (see Fig. S1 in the Supplement).

The volume size distribution is one of the significant properties of aerosol particles in the atmosphere column over an observational site because it provides insight into aerosol particles nature and origination. The standard AERONET inversion algorithm (Dubovik and King, 2000; Dubovik et al., 2000, 2006; Eck et al., 1999) provides these data under the assumption of a two-modal log-normal distribution law using sky radiance measurements along almucantar of the sun for SZA ranging from $75^{\circ}$ to $50^{\circ}$. Hence the majority of the size distribution data is obtained during period from April to September.

The monthly mean volume size distributions for April, May, August and September during 2000-2011 are shown in Figs. 3 and 4 with the exception of months when less than 5 retrievals are obtained. The figures display significant variability of the particle size distributions for each observational site in the same season from year to year. Some features of the size distributions under study have to be noted. The fine modes particles modal radius ranges from 0.1 to $0.2 \mu \mathrm{m}$ only, and the range of fine mode dispersions excepting some special events are rather close. It corresponds to homogeneous aerosols particles properties that are disturbed by events of intensive loading of aerosols to atmosphere. The coarse mode of the size distributions has a rather wide range of modal radius and dispersion. It corresponds to more various sources of coarse mode particles and their properties as mentioned above. Some special events responsible for the significant increase of relative contents of fine or coarse particles over the region of interest should be note.

The fine mode of particles relative content increased significantly in the Moscow region in April 2002, May 2006, August 2010 and September 2002. The coarse fraction particles maximum was observed in April 2009, May 2007, August 2010 and September 2003. These events may be explained by agricultural and forest wildfires in Russia since according to Remer et al. (1999) the biomass burning aerosol size distribution consists of accumulation and coarse mode. In addition, the volume fraction of coarse particles was larger than that of fine particles in May 2007 and 2011 that can be explained by the presence of soil dust in the atmosphere due to agricultural activity (Sterk and Goossens, 2007; Hinz and Funk, 2007).

The fine mode of particles relative contents increased predominantly in Minsk and Belsk in April and May 2006 particularly due to forest, peat, grass and shrubbery wildfires described in Stohl et al. (2007) and Lund Myhre et al. (2007). Moreover, agricultural burn events (Korontzi et al., 2006) were the basis for increasing of fine and coarse fraction aerosols in August and September 2002. Using a classification proposed by Yoon et al. (2012), the biomass burning, industrial and mixed aerosols are suspended in the atmosphere during this period (Fig. 2a). The coarse mode of particles content increasing was registered in May 2007 due

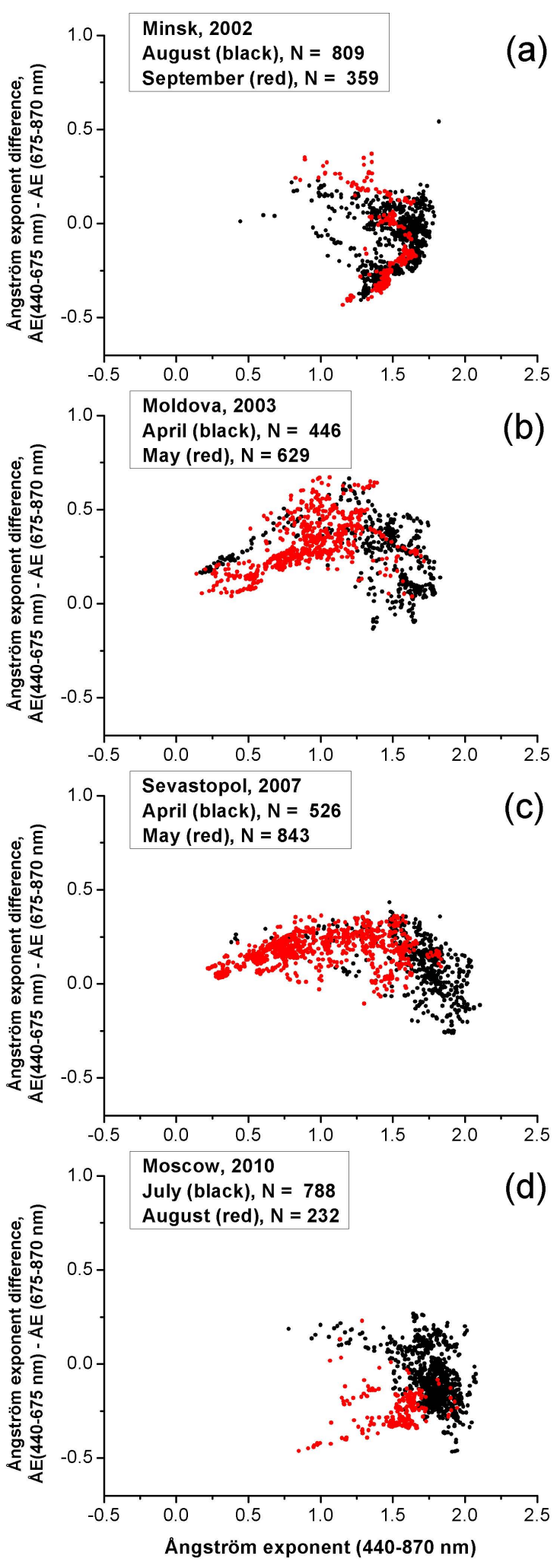

Fig. 2. The dependence of the Ångström exponent difference ( $\mathrm{E}(440-675 \mathrm{~nm})-\AA \AA \mathrm{E}(675-870 \mathrm{~nm}))$ from the Ångström exponent (440-870 nm) for Minsk (a), Moldova (b), Sevastopol (c) and Moscow (d) according to classification proposed by Yoon et al. (2012). 

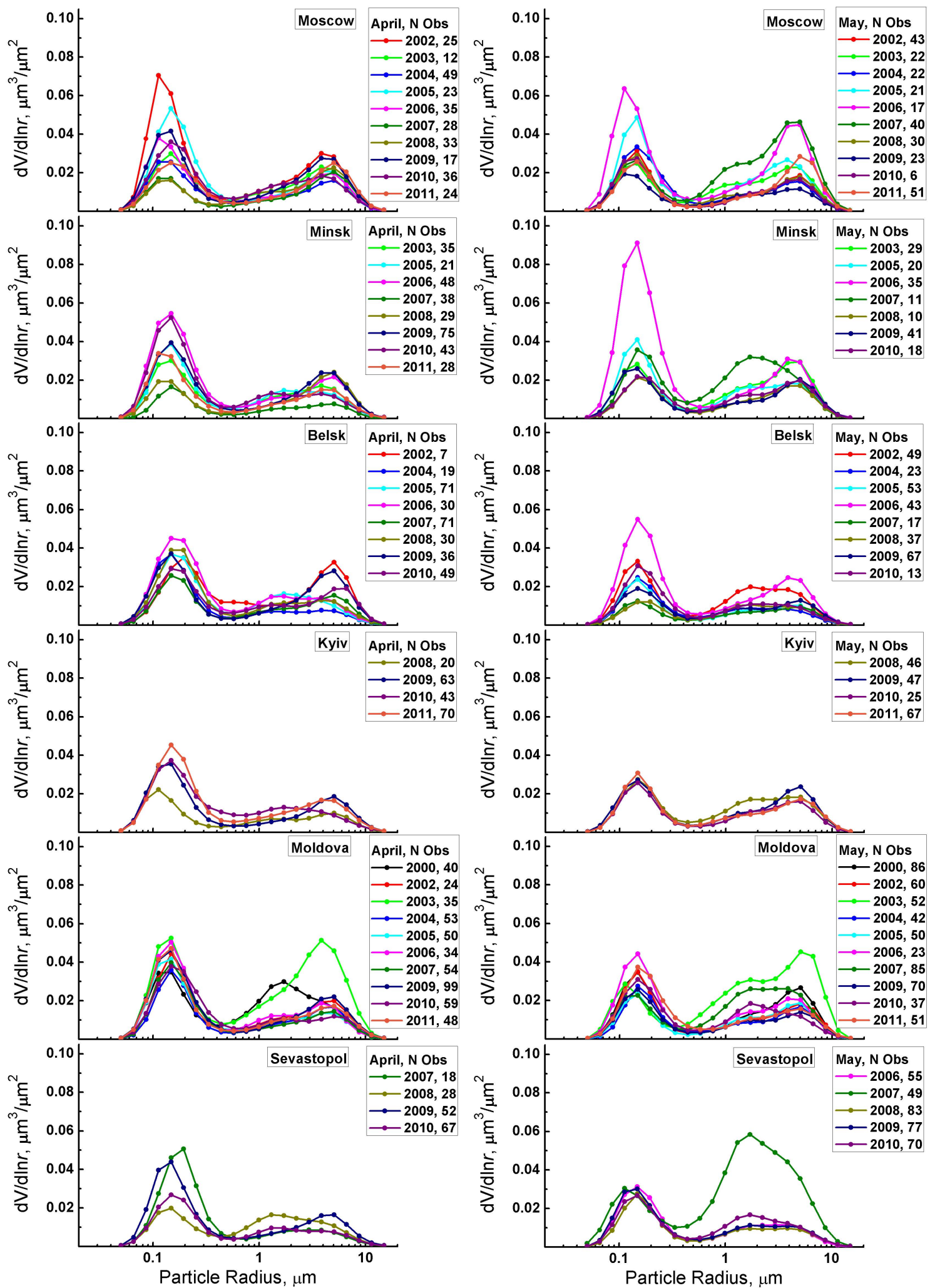

Fig. 3. Monthly mean volume aerosol particle size distribution and number of observations in April and May through 2000-2011 period. 

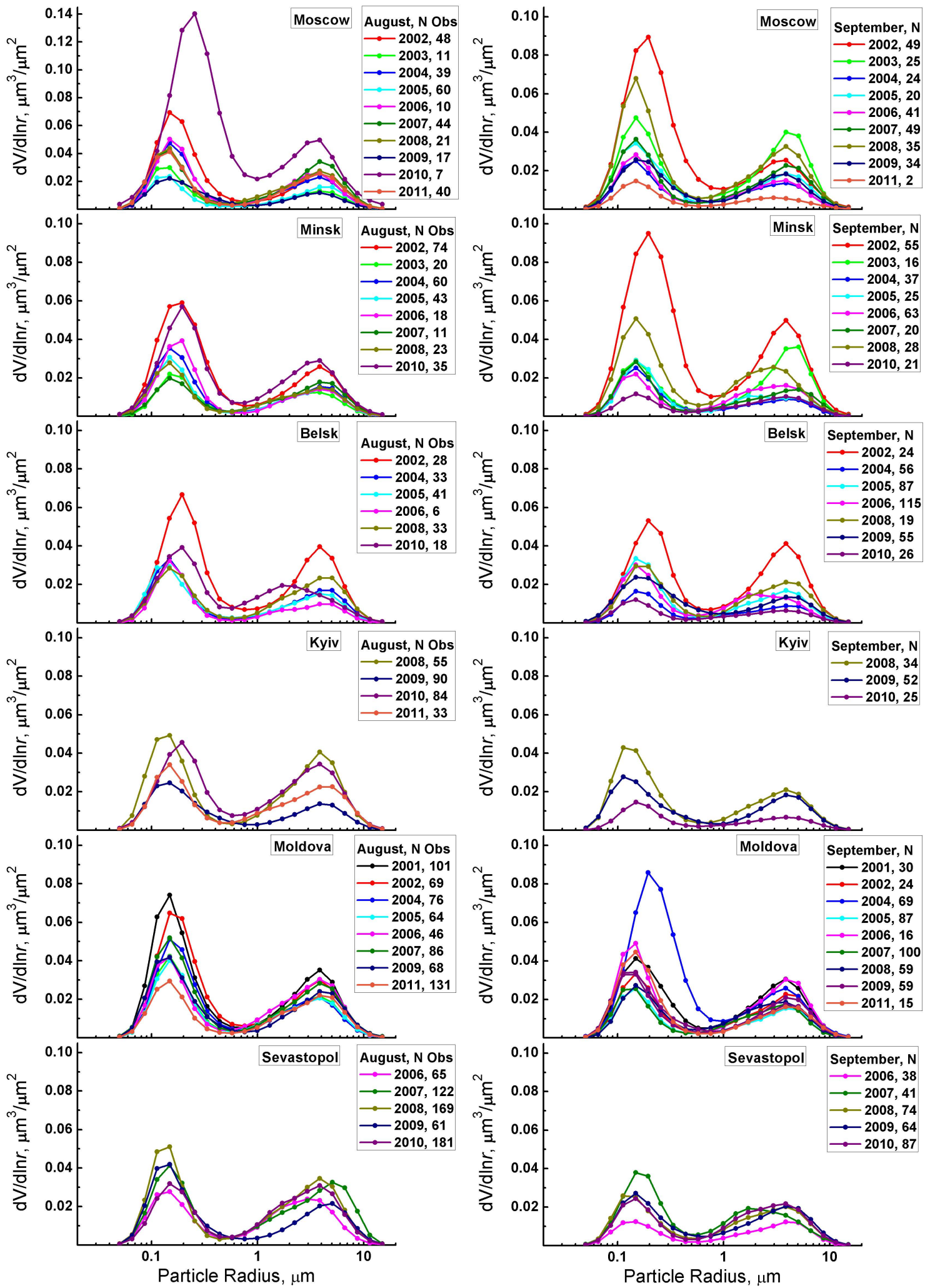

Fig. 4. Monthly mean volume aerosol particle size distribution and number of observations in August and September through 2000-2011 period. Note different axis scale of volume size distribution for August for Moscow site. 
to regional soil dust and transportation of Saharan dust (Israelevich et al., 2012; Papayannis et al., 2008). High aerosol loading was observed in Minsk, Belsk and Kyiv stations during strong wildfires in Russia in August 2010 (see Fig. S1 and S2 in the Supplement). The shifting of coarse mode of particles maximum was observed that probably can be explained by the decrease in size of biomass burning aerosols due to the distance of transportation.

The fine mode of particles prevailed mainly in Moldova during agricultural fires in August 2001, 2002 and September 2004. The coarse mode of particles growth was observed predominantly in April and May 2003 due to transportation of Saharan dust, sea salt and mixed aerosols as seen from Fig. 2b. Unfortunately, the sun photometer was calibrated during the wildfires in Russia in August 2010. As for the Sevastopol site, the biomass burning and urban aerosols are prevailed in April 2007 but dust and salt - in May 2007 (Fig. 2c). This indicates that different particles can be dominate in spring for the same location. Moreover, the increase of the coarse mode of particles was observed in August of each considered year.

In summary the different aerosol types are presented in the atmosphere over the Eastern Europe region during the year. Using the classification of aerosol types discussed by Yoon et al. (2012) and analysis of the volume size distribution, the special events were analyzed to show particles variability in the period from 2003 to 2011. Additionally, near-surface wind speed is known to cause the increase in amounts of several aerosols types, e.g., sea salt, dust, primary organic particles, and burn particles (IPCC, 2007). Therefore, in order to qualify the possible reasons of AOT change the data from the NCEP reanalysis (/http://esrl.noaa.gov/) at the NCAR Climate Data (https://climatedataguide.ucar.edu) were used to characterize $925 \mathrm{hPa}$ wind fields over Eastern Europe for the period 2001-2011 (see Fig. S2 in the Supplement). These results are essential when analyzing satellite data.

\section{Analysis of aerosols in the atmosphere using satellite data}

The experience of satellite remote sensing has showed that only multi-spectral, multi-directional and polarized measurements provide the robust aerosol properties retrieval over land because radiance reflected from earth's surface has small polarization, while fine aerosol particles polarize light substantially, and thereby the polarized satellite measurements are adequate only for aerosol studies over land. The POLDER (POLarization and Directionality of the Earth Reflectance) instrument (Deschamps et al., 1994) meets these features because it carries out multi-spectral $(443,490,565$, $670,763,765,865,910$ and $1020 \mathrm{~nm}$ ), multi-directional (as many as 16 directions within the scope of $100^{\circ}$ approximately along ground trace) measurements of intensity and linear polarization degree of back-scattered solar radiation.
The POLDER-1 instrument was launched on board ADEOS satellite in August 1996 with operation time till June 1997. The POLDER-2 instrument flew aboard ADEOS-2 from April to October 2003. The POLDER-3 was launched aboard French microsatellite PARASOL (part of the A-Train satellite constellation) in December 2004 and has been collecting data since March 2005.

The spectral distribution of scattered light intensity allows us to estimate aerosol particle sizes and thus their scattering phase function, as well as the AOT. The polarization provides information on aerosol refractive index and shape (spherical or non-spherical), which improves the precision of the scattering phase function. The current standard aerosol inversion strategy detailed in Deuzé et al. (2001) is based on the lookup tables approach, where the reflected radiances are simulated for 10 aerosol models with log-normal size distributions of particles with effective radius from 0.075 to $0.225 \mu \mathrm{m}$, refractive index $m=1.47-0.01 i$ which corresponds to a mean value for aerosols resulting from biomass burning or pollution events (Dubovik et al., 2002a) and the Ångström exponent calculated for 670 and $865 \mathrm{~nm}$ between 1.8 and 3. The aerosol parameters are adjusted to give the best agreement between the measured and simulated multidirectional polarized radiances at $670 \mathrm{~nm}$ and $865 \mathrm{~nm}$ wavelengths. The surface contribution to the polarized reflectance is based on a priori values (as a function of observation geometry and surface type) derived from statistical analysis of POLDER data (Nadal and Bréon, 1999).

The characteristics of earth's surface are taken into account in the form of empirical coefficients which are chosen for different classes of land surface according to the main International Geosphere-Biosphere Programme (IGBP) biotypes and the normalized difference vegetation index (NDVI) (Nadal and Bréon, 1999). Moreover, the polarized light reflected by the surface is wavelength independent. It should be noted that larger particles, such as dust and sea salt, almost do not polarize sunlight and are therefore hardly detected from polarization measurements.

The spectroradiometer POLDER data were processed and were described at http://www.icare.univ-lille1.fr/parasol/. earth's surface reflection coefficients are obtained from maximum 16 directions for POLDER/PARASOL and from 14 directions for POLDER-1, -2 with resolution $6 \mathrm{~km} \times 6 \mathrm{~km}$, while aerosol parameters are estimated with resolution $3 \times$ 3 pixels, i.e., approximately $18 \mathrm{~km} \times 18 \mathrm{~km}$. The spectral polarized radiances (Level 1 data) performed at $670 \mathrm{~nm}$ and $865 \mathrm{~nm}$ wavelengths are used to derive AOT over cloud-free regions (Level 2 data).

The monthly mean (Level 3 data) AOT values at $865 \mathrm{~nm}$ for April, May, August and September from POLDER-2 and POLDER/PARASOL through 2003-2011 period except 2004 (measurements were not performed) are used to analyze aerosol loading in the atmosphere over Eastern Europe. The results are presented in Fig. 5. The territory is characterized 


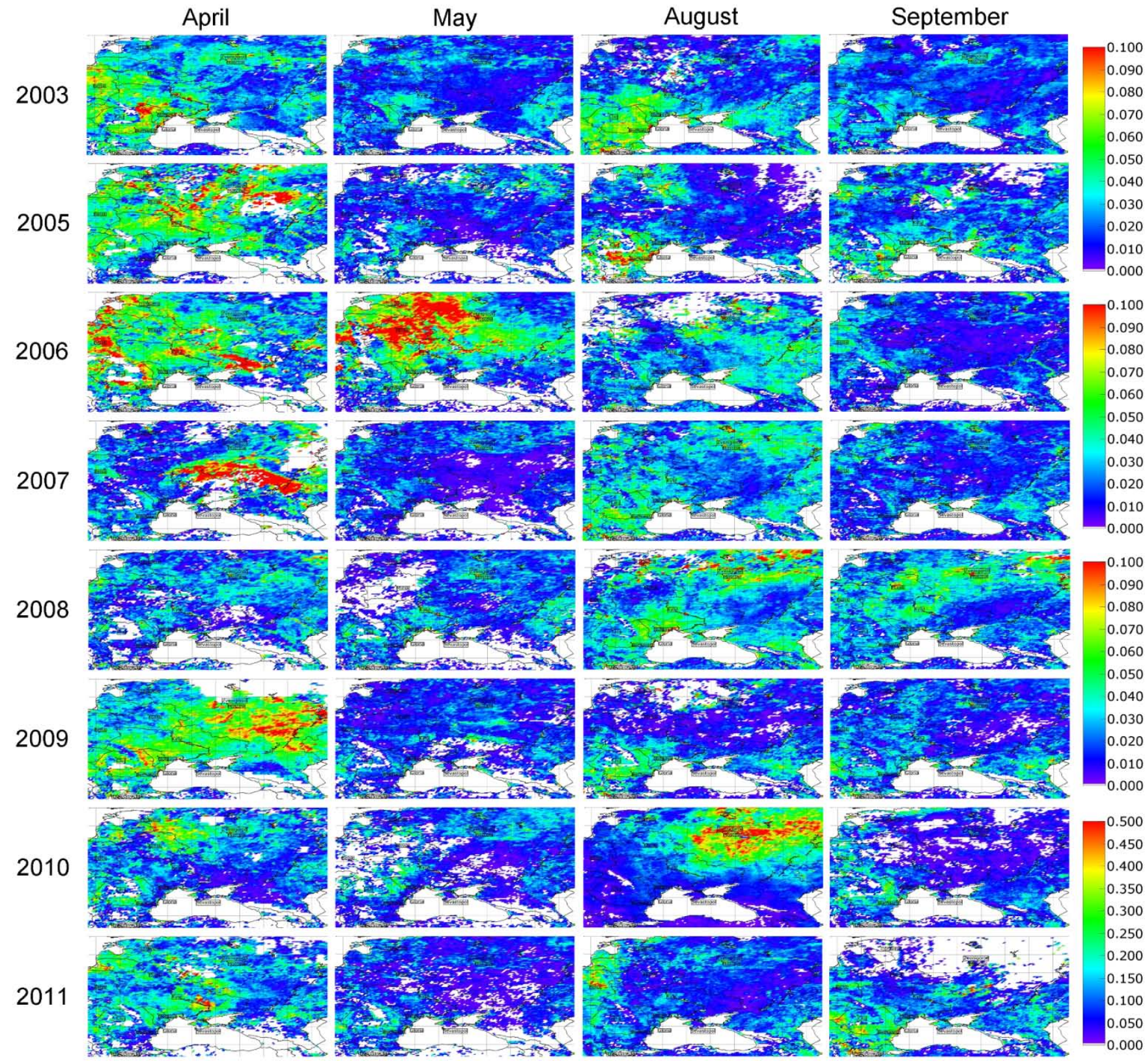

Fig. 5. Maps of monthly average AOT at $865 \mathrm{~nm}$ received from POLDER-2/ADEOS-2 and POLDER/PARASOL for April, May, August and September through 2003 - 2011. Note bottom AOT scale with maximum value 0.5 only for August 2010 map.

by low AOT in comparison with industrial regions of East Asia and African dust events.

The high value of AOT in April-May and AugustSeptember is generally explained by agricultural fires, pollution of uncontrollable forest and peat wildfires, as well as transportation of Saharan dust over the Mediterranean to Eastern Europe in April and August-September. According to the National report on technological and natural safety (2011) by the Ministry of Ecology and Natural Resources of Ukraine the number of forest, peat and agricultural fires and burnt areas has decreased over the last 5 yr. In 2005, the total of 4223 fires took place with $26 \mathrm{~km}^{2}$ burnt areas. The number of fires had been decreasing since 2005 and reduced to 1780 events with $6 \mathrm{~km}^{2}$ burnt area in 2011. The most extensive wildfire events were observed in May 2006 when aerosol amount in the atmosphere increased due to transportation of aerosols from the wildfires in Belarus (Stohl et al., 2007; Lund Myhre et al., 2007) and in western Russia in April 2009. The AOT values registered at $865 \mathrm{~nm}$ ranged from 0.1 to 0.15 in the first event and 0.07 to 0.15 in the second event. The aerosol transboundary transportation from western Russia and north Ukraine strong forest 
and peat fires in the mid-July-August of 2010 (Konovalov et al., 2011; Chubarova et al., 2012; Witte et al., 2011) produced increased AOT values to $0.2-0.5$ (Fig. 5). Sea salt aerosols are usually transported to Ukraine and Moldova from the Black and Azov seas by south winds in April-May (Fig. 2b) but the particles with size $0.5-4 \mu \mathrm{m}$ are hardly detected from polarization measurements due to sensitivity of POLDER/PARASOL retrievals to the smaller fraction of fine particles (Fan et al., 2008; Su et al., 2010; Gu et al., 2011).

According to our research the values of AOT are higher over the central Ukraine and Belarus, the whole territory of Moldova and over Moscow region in Russia. However, the amount of aerosols has decreased since 2009 which is caused particularly by reduction of burnt areas. Moreover, a small decrease of anthropogenic aerosols in industrial regions can be observed from May 2009 to August 2011 in the result of global economic crisis when many factories and plants reduced their output.

\section{Comparison of AERONET and POLDER data}

\subsection{Current standard aerosol inversion}

The significant correlation (0.84) between satellite and ground-based measurements has been obtained over land surface (Bréon et al., 2011) where POLDER algorithm only retrieves the "fine mode" optical depth. However, some discrepancy in the definition of "fine mode" leads to underestimation of the satellite retrieval results compared to AERONET data. In the regions where dust-loaded atmospheres are excluded, i.e., in the regions affected by biomass burning or pollution aerosols, the comparison with AERONET measurements shows better results with small bias (Bréon et al., 2011; Tanré et al., 2011). A specific comparison study (Fan et al., 2008; Su et al., 2010) of AERONET data over East Asia with POLDER/PARASOL observations demonstrates the POLDER instrument capability to determine the anthropogenic contribution $(r<0.3 \mu \mathrm{m}$, where $r$ - particle radius) to regional aerosol load. Additionally, $\mathrm{Gu}$ et al. (2011) have showed that the sensitive radius for polarized aerosol retrieval is $0.35 \mu \mathrm{m}$ for all seasons in 2005-2009 for Beijing (China) and Kanpur (India).

The PARASOL satellite overpass time for the investigated territory is 10:00-11:30 UT depending on the orbit. The domains with $3 \times 3$ pixels of Level $2(54 \mathrm{~km} \times 54 \mathrm{~km})$ were selected so that the central pixel covered the site equipped by sun photometer. Moreover, we chose the days when minimum 6 pixels from the domain were retrieved on condition that measurements were collected at least at 9 different angles. Since POLDER derived AOTs are sensitive to the fine aerosol mass concentration (Fan et al., 2008; Su et al., 2010) in our research we used all the retrieved parameters from AERONET to recompute this integral over the size distribution and stop integration at $0.3 \mu \mathrm{m}$. In analyzing AERONET data, we adopted a methodology similar to that used by $\mathrm{Su}$ et al. (2010). Consequently, the AOT values correspond to particles with $r<0.3 \mu \mathrm{m}$ have been computed for all the data (Level 2.0). We selected the AOTs that were measured within \pm 30 min of the satellite overpass times and on condition that AOT variation in this lapse of time did not exceed $25 \%$ of the daily mean. Furthermore, we excluded AOT zero values received by POLDER (lack of phase angles or cloudiness) from our analysis as well. After selecting the required data, we compared POLDER AOT derived from the central pixel and recomputed AERONET AOT which satisfied the above requirements. The results of the comparison for Kyiv and Sevastopol sites over the period from 2008 to 2009 and for Moscow, Minsk, Belsk and Moldova sites over the period from 2005 to 2009 are presented in Fig. 6.

In general, there is a good agreement between the AERONET fine mode AOT and the POLDER AOT over all sites except Sevastopol. The correlation coefficients are 0.78 for Moscow, 0.76 for Minsk, 0.86 for Belsk, 0.93 for Kyiv, 0.81 for Moldova and 0.63 for Sevastopol sites with STD less than 0.02 for AOT values variation between 0.01 and 0.25 that is not exceed the accuracy assessed in Mishchenko et al. (2004) where over land the measurement accuracy should be better than 0.04. As seen from Fig. 6 the slopes are approximately 1 for Minsk (0.97), Kyiv (0.99) and Moldova (1.01), and equal 0.83 for Moscow, 1.13 for Belsk and 0.74 for Sevastopol. It should be noted that the number of data increased for the sites at smaller latitude and greater quantity of sunshine days, i.e., Moldova and Sevastopol. The high deviation in Sevastopol site may be explained by the spatial variation of surface polarization at the coastal land. The surface impact on polarization is relatively greater when the amount of aerosol in the atmosphere is small. The underlying surface in the investigated region varies highly in spring and autumn due to snow and vegetative cover. The deviation could also be explained by the same cutoff of fine mode particles $(r<0.3 \mu \mathrm{m})$ while the presence of different aerosol types over each site can lead to changing this limit. For instance, AERONET station in Sevastopol is a coastal site where sea salt particles are present (Manders et al., 2010; Aan de Brugh et al., 2011; Novikova, 2009) throughout the year (for AprilMay 2003 shown in Fig. 2b).

\subsection{Potential of new generation algorithms for retrieving enhanced aerosol properties from space}

Finally, we have analyzed a limited data set of aerosol properties derived over AERONET sites by the new generation of PARASOL aerosol retrieval algorithm which provides information about all size particles. In contrast to most satellite retrieval approaches the new state-of-art algorithm (Dubovik et al., 2011) does not use a look-up table. Instead, it implements all the radiative transfer calculations on line and searches for the solution in continuous space of aerosol solutions. This algorithm is an attempt 

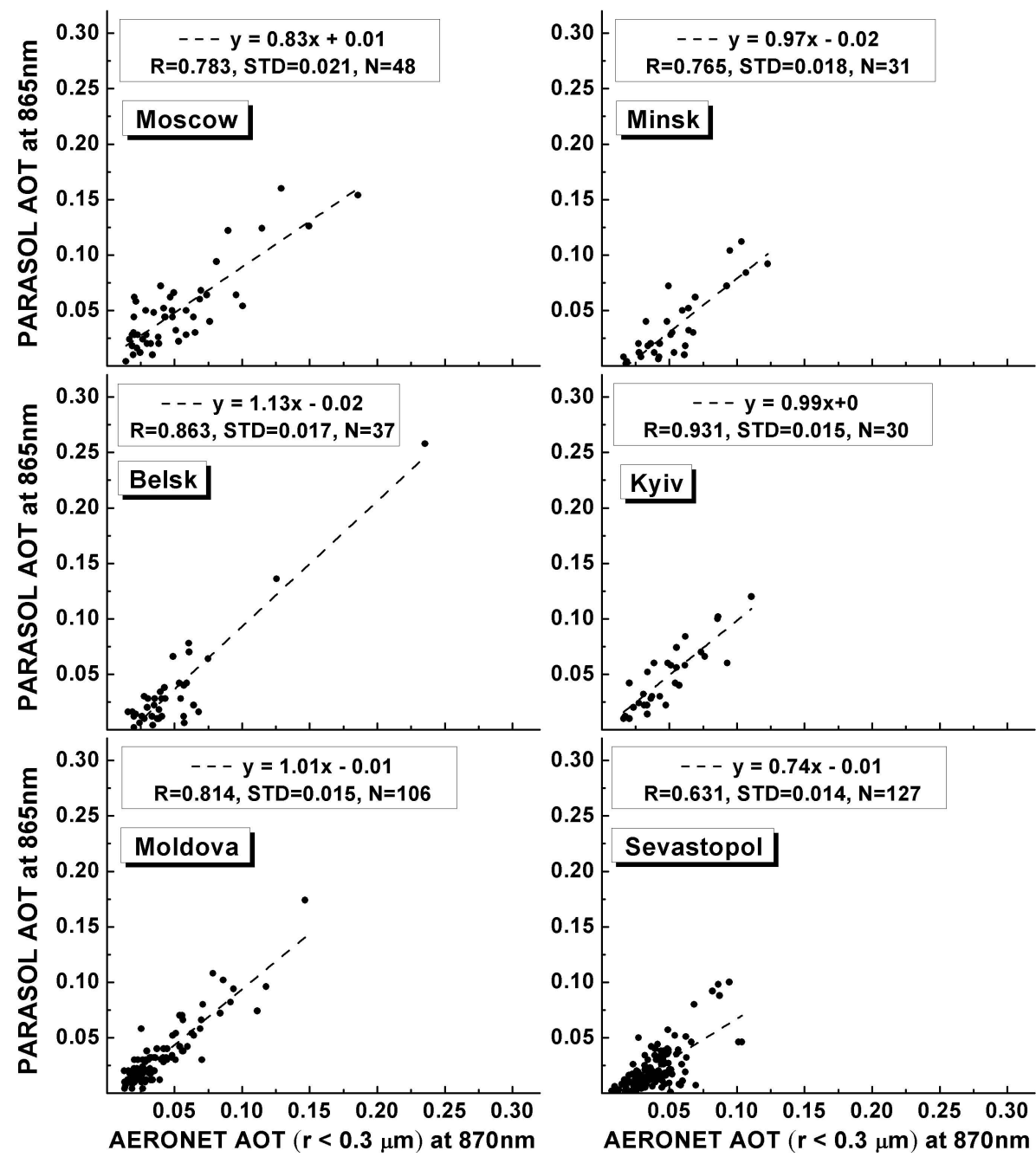

Fig. 6. Comparison of POLDER/PARASOL AOT865 and AERONET fine mode $(\mathrm{r}<0.3 \mu \mathrm{m})$ AOT870 for Moscow, Minsk, Belsk, Kyiv, Moldova and Sevastopol sites.

to enhance aerosol retrieval by emphasizing statistical optimization using the positive data redundancy (Dubovik, 2004; Dubovik et al., 2011) available from advanced multi-angular polarimetric satellite spectral observations such as those by POLDER/PARASOL. Based on this strategy, the algorithm aims at retrieving an extended set of aerosol parameters including particle size distribution, complex refractive index, as well as some parameters characterizing aerosol particle shape and vertical distribution. The high potential of this approach is confirmed by "blind test" intercomparison of satellite retrievals over dark surface by Kokhanovsky et al. (2010). The results of these tests showed that new PARASOL retrieval algorithm provides the most accurate and complete aerosol retrieval from synthetic data.

In addition, the approach allows for retrieving not only optical properties of aerosol but also underlying surface reflectance over land. In order to achieve a robust retrieval of both, the algorithm uses a so-called "multi-pixel" retrieval regime where the inversion of satellite data is performed simultaneously for a large group of pixels. The approach allows for applying additional a priori constraints on temporal variability of surface reflectance and spatial variability of aerosol properties. The first applications of the algorithm to real PARASOL data by Dubovik et al. (2011) show a promising agreement of the retrieved values of POLDER AOT with AERONET data with correlation coefficient of $\sim 0.9$ for Banizoumbou (Niger) and $\sim 0.87$ for Mongu (Zambia).

In comparison with the PARASOL standard algorithm, the new algorithm provides more aerosol parameters and describes the surface reflectance with higher robustness. However, since the algorithm performs all radiation computation on line, the time required to implement the algorithm is significantly longer compared to the conventional look-up table algorithms. This limitation is expected to be addressed in the near future by parallel programming and implementing the 

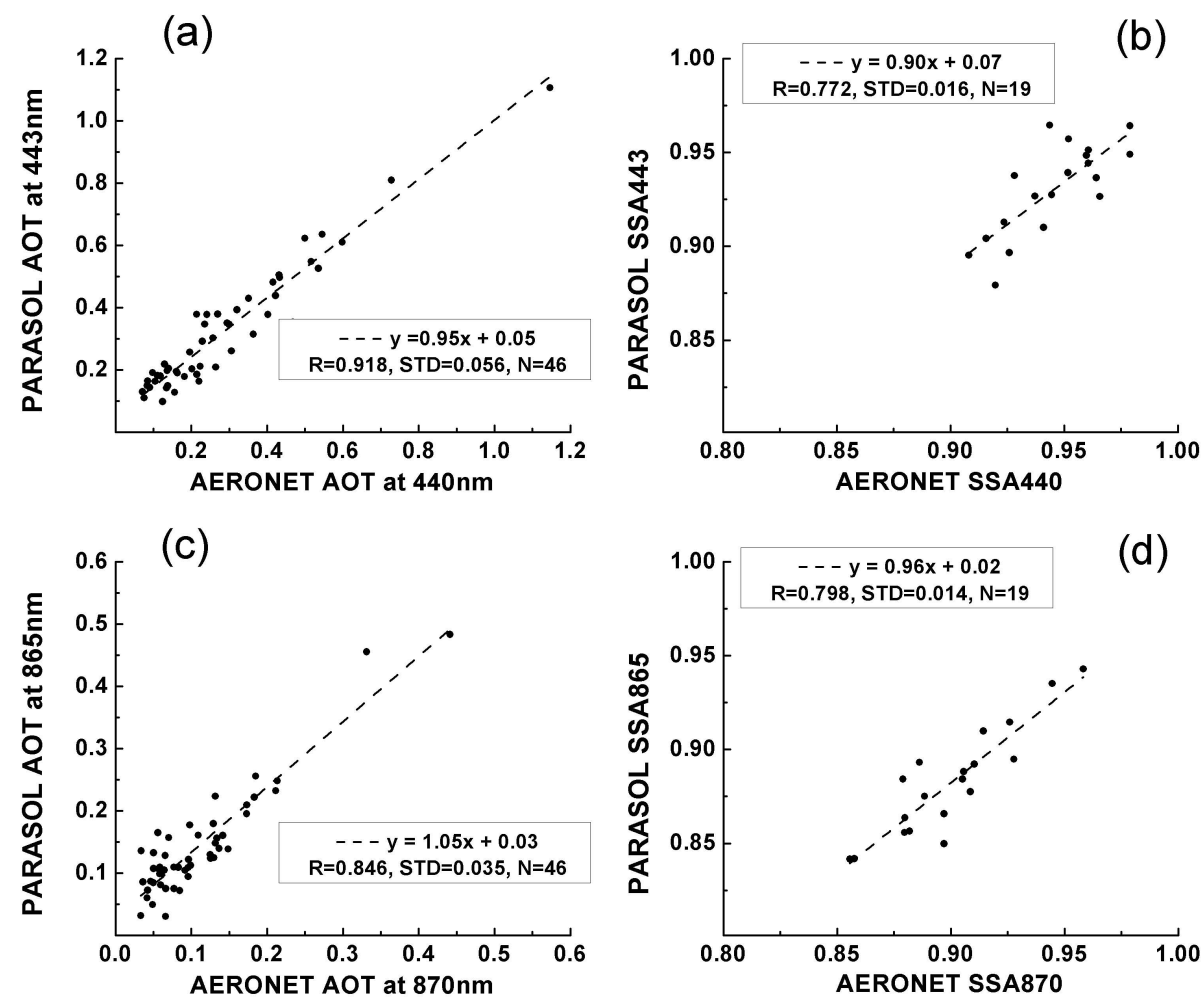

Fig. 7. Comparison of AOT440 (a), SSA440 (b) and AOT870 (c), SSA870 (b) retrieved from POLDER/PARASOL and AERONET observations over Kyiv through 2008-2011 period.

retrievals at the network of computers that operate in parallel.

The new algorithm was applied for POLDER/PARASOL data obtained over Kyiv AERONET site for the period from 2008 to 2011. According to the numerical tests (Dubovik et al., 2011) multi-pixel retrieval was selected for data processing. The data were chosen in conditions when time difference between AERONET measurement (Level 2.0) and POLDER/PARASOL overpass did not exceed $30 \mathrm{~min}: 18 \mathrm{el}-$ igible days in 2008, 14 days in 2009, 7 days in 2010 and in 2011. It should be noted that the days with stable AOT value and cloudless weather conditions according to AERONET measurements were compared. The time difference between satellite and ground-based data time acquisition is smaller in spring and autumn and larger in summer (due to geometry of measurements and satellite orbit) while in winter the eligible measurements were not collected due to clouds and snow.

The comparison of AOT440 (Fig. 7a), SSA440 (Fig. 7b), AOT870 (Fig. 7c), and SSA870 (Fig. 7d). retrieved from POLDER/PARASOL observations over Kyiv with the corresponding values provided by AERONET in 2008-2011 are presented in Fig. 7. The variability SSA retrieved from PARASOL/AERONET data is in good agreement and shows the STD value less than 0.02 . It should be noted that comparison of SSA was accomplished only for 19 days due to less frequent scanning along the almucantar and in the prin- cipal plane of the sun than in the direct sun during satellite overpass time (10:00-11:30 UT). For AOT comparison STD values are in the range $0.04-0.06$. That is not adequate in full from the standpoint of aerosol radiative forcing estimates and needs to be better (Mishchenko et al., 2004). Large AOT440 STD values can probably be explained by sky inhomogeneity in PARASOL observed pixels. Note that AOT440 reaches the maximum value 1.14 , which is caused by smoke aerosols from the forest and peat fires in August 2010 and can increase obtained STD value. It should be emphasized that we present preliminary results from those that can be provided by the new PARASOL algorithm. We expected to achieve retrievals of higher quality once the algorithm will be fully tuned and validated in operational PARASOL data processing.

\section{Conclusions}

The aim of this article was to study of aerosol variability over the Eastern Europe region (LAT: from $40^{\circ} \mathrm{N}$ to $60^{\circ} \mathrm{N}$, LONG: $20^{\circ} \mathrm{E}$ to $50^{\circ} \mathrm{E}$ ). This region is considered to be a source of both natural and anthropogenic aerosols. We have analyzed aerosol distribution for the period of 2003-2011 using satellite POLDER/PARASOL and POLDER-2/ADEOS2 measurements of aerosol characteristics and AERONET ground-based sun photometer data. The typical aerosol loading over these territories is characterized by the AOT values 
(at $870 \mathrm{~nm}$ ) ranging from 0.05 to 0.2 . Different methods of aerosol types classification have been applied to get more enhanced and improved results.

Seasonal variability of aerosol amount is characterized by two high peaks in April-May and August-September. The spring peak is explained by incidental transportation of Saharan dust in the atmospheric layer over Eastern Europe, infrequent agricultural fires, transportation of sea salt aerosols to Ukraine and Moldova from the Black and Azov seas by southern winds. Correspondingly, the values of Ångström exponent are higher in April-May which is explained by the increased amount of fine fraction particles.

The August-September peak is associated with forest and peat wildfires, and autumn season of transportation of Saharan dust. Moreover, the strong surface wind can cause the transportation of the soil dust aerosol (Gross and Barring, 2003; Bessagnet et al., 2008; Ginoux et al., 2001) on hundreds of kilometers during harvesting activity (Sterk and Goossens, 2007; Hinz and Funk, 2007).

The aerosols observed over industrial areas of the Eastern Europe region are presumably of anthropogenic origin. According to the analysis of the AOT distribution, higher values are observed over the central Ukraine and Belarus, the whole territory of Moldova and over Moscow region in Russia. A small anthropogenic aerosols decrease over industrial regions can be observed from May 2009 to August 2011, which is probably caused by the global economical crisis when many factories and plants reduced the production.

In summary the different aerosol types are presented in the atmosphere over the Eastern Europe region during the year. Consequently, the comparison of satellite and ground-based measurements of aerosol characteristics has been presented to show all features and limitation of both retrievals.

The comparison of the AOTs obtained from POLDER/PARASOL observations standard algorithm with fine mode AOTs (particle radius $<0.3 \mu \mathrm{m}$ ) recomputed from AERONET inversions has shown that the correlation coefficients for satellite and ground-based data are 0.78 for Moscow, 0.76 for Minsk, 0.86 for Belsk, 0.93 for Kyiv, 0.81 for Moldova and 0.63 for Sevastopol. The deviation is explained by spatial variations of surface polarization used in the retrieval, since the surface impact on satellite observations is higher in the atmospheric conditions with small aerosol loading. Nevertheless, the STD is not exceed the accuracy assessed in Mishchenko et al. (2004) where over land the measurement accuracy should be better than 0.04. In other words the standard POLDER/PARASOL inversion can be used to characterize the anthropogenic aerosols despite the limitation on the particle size $(0.3 \mu \mathrm{m})$.

The results obtained by the algorithm developed recently by Dubovik et al. (2011) have been compared with the AERONET data for Kyiv site (Level 2.0). In comparison with PARASOL standard algorithm the new algorithm provides information about all size particles and describes the surface reflectance with higher robustness. Since the new re- trievals from POLDER/PARASOL have preliminary character, the presented analysis of the newly derived aerosol characteristics is somewhat limited. The comparison of the derived aerosol properties with available observations by AERONET ground-based sun photometer indicates rather promising consistency of PARASOL derived optical thickness and single scattering albedo with those obtained by AERONET.

With the aim to provide possible explanations for the general agreement and differences between aerosol properties retrieved from satellites and those observed at ground-based stations, future work should analyze in more details an extended set of aerosol parameters including particle size distribution, complex refractive index, as well as some parameters characterizing aerosol particle shape and vertical distribution. These studies should propose the extensive validation of satellite retrievals and combination of both data sets in order to decrease the uncertainties in determining of aerosol characteristics.

\section{Supplementary material related to this article is available online at: http://www.atmos-chem-phys.net/13/ 6587/2013/acp-13-6587-2013-supplement.pdf.}

Acknowledgements. The work was supported by project M/692009 "Dnipro" in the framework of scientific cooperation between Kyiv National Taras Shevchenko University, Main Astronomical Observatory of NAS of Ukraine and Laboratoire d'Optique Atmosphérique, Lille, France (LOA, UMR 8518 CNRS-Lille1). This publication is partly supported by Award No. UKG2-2969-KV-09 of the US Civilian Research \& Development Foundation (CRDF), by project F41/106-2012 Derzhinformnauky of Ukraine, by MONmolod'sport of Ukraine project M/115-2012 and by Taras Shevchenko National University of Kyiv, project 11BF051-01. The authors thank the ICARE Data and Services Center team for providing access to the PARASOL data and for general assistance and development support. We thank B. Holben (NASA-GSFC) for managing the framework of the AERONET program and the sites, we appreciate effort in establishing and maintaining AERONET sites by PIs: P. Sobolewski and A. Pietruczuk (the Belsk site), A. Chaikovsky (the Minsk site), N. Chubarova (the Moscow site), and A. Aculinin (the Moldova site). CIMEL sun photometers calibration was performed at LOA using AERONET-EUROPE calibration center, supported by ACTRIS (European Union Seventh Framework Program (FP7/2007-2013) under grant agreement No. 262254). The authors are grateful to T. Lapyonok for the help in processing data using new algorithm developed by O. Dubovik. The authors thank two anonymous referees for detailed comments and useful suggestions.

Edited by: M. King 


\section{References}

Aan de Brugh, J. M. J., Schaap, M., Vignati, E., Dentener, F., Kahnert, M., Sofiev, M., Huijnen, V., and Krol, M. C.: The European aerosol budget in 2006, Atmos. Chem. Phys., 11, 1117-1139, doi:10.5194/acp-11-1117-2011, 2011.

Aculinin, A., Holben, B., Smirnov, A., and Eck, T.: Measurements of aerosol optical properties at the Kishinev site, Moldova, Moldav. J. Phys. Sci., 3, 214-225, 2004.

Amiridis, V., Balis, D. S., Giannakaki, E., Stohl, A., Kazadzis, S., Koukouli, M. E., and Zanis, P.: Optical characteristics of biomass burning aerosols over Southeastern Europe determined from UVRaman lidar measurements, Atmos. Chem. Phys., 9, 2431-2440, doi:10.5194/acp-9-2431-2009, 2009.

Amiridis, V., Giannakaki, E., Balis, D. S., Gerasopoulos, E., Pytharoulis, I., Zanis, P., Kazadzis, S., Melas, D., and Zerefos, C.: Smoke injection heights from agricultural burning in Eastern Europe as seen by CALIPSO, Atmos. Chem. Phys., 10, 11567-11576, doi:10.5194/acp-10-11567-2010, 2010.

Amodeo, A., Bosenberg, J., Ansmann, A., Balis, D., Bockmann, C., Chaikovsky, A., Comeron, A., Mitev, V., Papayannis, A., Pappalardo, G., Perrone, M. R., Rizi, V., Simeonov, V., Sobolewski, P., Spinelli, N., Stoyanov, D., Trick, T., Wiegner, M.: EARLINET: the European Aerosol Lidar Network, Opt. Pur. Apl., 39, 1-10, 2006.

Barnaba, F., Angelini, F., Curci, G., and Gobbi, G. P.: An important fingerprint of wildfires on the European aerosol load, Atmos. Chem. Phys., 11, 10487-10501, doi:10.5194/acp-1110487-2011, 2011.

Bessagnet, B., Menut, L., Aymoz, G., Chepfer, H., and Vautard, R.: Modeling dust emissions and transport within Europe: the Ukraine March 2007 event, J. Geophys. Res., 113, D15202, doi:10.1029/2007JD009541, 2008.

Birmili, W., Schepanski, K., Ansmann, A., Spindler, G., Tegen, I., Wehner, B., Nowak, A., Reimer, E., Mattis, I., Müller, K., Brüggemann, E., Gnauk, T., Herrmann, H., Wiedensohler, A., Althausen, D., Schladitz, A., Tuch, T., and Löschau, G.: A case of extreme particulate matter concentrations over Central Europe caused by dust emitted over the southern Ukraine, Atmos. Chem. Phys., 8, 997-1016, doi:10.5194/acp-8-997-2008, 2008.

Boersma, K. F. and de Vroom J. P.: Validation of MODIS aerosol observations over the Netherlands with GLOBE student observations, J. Geophys. Res., 111, D20311, doi:10.1029/2006JD007172, 2006.

Bréon, F.-M., Vermeulen, A., and Descloitres, J.: An evaluation of satellite aerosol products against sunphotometer measurements, Remote Sens. Environ., 115, 3102-3111, doi:10.1016/j.rse.2011.06.017, 2011.

Chin, M., Kahn, R. A., and Schwartz, S. E. (Eds.): Atmospheric Aerosol Properties and Climate Impacts, a Report by the U.S. Climate Change Science Program and the Subcommittee on Global Change Research, National Aeronautics and Space Administration, Washington, DC, USA, 128 pp., 2009.

Chubarova, N., Nezval', Ye., Sviridenkov, I., Smirnov, A., and Slutsker, I.: Smoke aerosol and its radiative effects during extreme fire event over Central Russia in summer 2010, Atmos. Meas. Tech., 5, 557-568, doi:10.5194/amt-5-557-2012, 2012.

Deschamps, P. Y., Bréon, F.-M., Leroy, M., Podaire, A., Bricaud, A., Buriez, J. C., and Seze, G.: The POLDER mission: Instrument characteristics and scientific objectives, IEEE T. Geosci. Remote,
32, 598-615, 1994.

Deuzé, J.-L., Bréon, F.-M., Devaux, C., Goloub, P., Herman, M., Lafrance, B., Maignan, F., Marchand, A., Perry, G., and Tanré, D.: Remote Sensing of aerosols over land surfaces from POLDER/ADEOS-1 polarized measurements, J. Geophys. Res., 106, 4913-4926, doi:10.1029/2000JD900364, 2001.

Dubovik, O.: Optimization of numerical inversion in photopolarimetric remote sensing, in: Photopolarimetry in Remote Sensing, edited by: Videen, G., Yatskiv, Y., and Mishchenko, M., Kluwer Academic Publishers, Dordrecht, the Netherlands, 65-106, 2004.

Dubovik, O. and King, M. D.: A flexible inversion algorithm for retrieval of aerosol optical properties from Sun and sky radiance measurements, J. Geophys. Res., 105, 20673-20696, 2000.

Dubovik, O., Smirnov, A., Holben, B. N., King, M. D., Kaufman, Y. J., Eck, T. F., and Slutsker, I.: Accuracy assessment of aerosol optical properties retrieval from AERONET sun and sky radiance measurements, J. Geophys. Res., 105, 9791-9806, 2000.

Dubovik, O., Holben, B. N., Eck, F. T., Smirnov, A., Kaufman, J. Y., King, D. M., Tanré, D., and Slutsker, I.: Variability of absorption and optical properties of key aerosol types observed in worldwide locations, J. Atmos. Sci., 59, 590-608, 2002a.

Dubovik, O., Holben, B. N., Lapyonok, T., Sinyuk, A., Mishchenko, M. I., Yang, P., and Slutsker, I.: Non-spherical aerosol retrieval method employing light scattering by spheroids, Geophys. Res. Lett., 29, 1415, doi:10.1029/2001GL014506, 2002b.

Dubovik, O., Sinyuk, A., Lapyonok, T., Holben, B. N., Mishchenko, M., Yang, P., Eck, T. F., Volten H., Muñoz, O., Veihelmann, B., van der Zande, W. J., Leon, J.-F., Sorokin, M., and Slutsker, I.: Application of spheroid models to account for aerosol particle nonsphericity in remote sensing of desert dust, J. Geophys. Res., 111, D11208, doi:10.1029/2005JD006619, 2006.

Dubovik, O., Herman, M., Holdak, A., Lapyonok, T., Tanré, D., Deuzé, J. L., Ducos, F., Sinyuk, A., and Lopatin, A.: Statistically optimized inversion algorithm for enhanced retrieval of aerosol properties from spectral multi-angle polarimetric satellite observations, Atmos. Meas. Tech., 4, 975-1018, doi:10.5194/amt-4975-2011, 2011.

Eck, T. F., Holben, B. N., Reid, J. S., Dubovik, O., Kinne, S., Smirnov, A., O'Neill, N. T., and Slutsker, I.: The wavelength dependence of the optical depth of biomass burning, urban and desert dust aerosols, J. Geophys. Res., 104, 31333-31350, 1999.

Eck, T. F., Holben, B. N., Reid, J. S., O’Neill, N. T., Schafer, J. S., Dubovik, O., Smirnov, A., Yamasoe, M. A., and Artaxo P.: High aerosol optical depth biomass burning events: a comparison of optical properties for different source regions, Geophys. Res. Lett., 30, 2035, doi:10.1029/2003GL017861, 2003.

Fan, X. H., Goloub, P., Deuzé, J. L., Chen, H. B., Zhang, W. X., Tanré, D., and Li, Z. Q.: Evaluation of PARASOL aerosol retrieval over North East Asia, Remote Sens. Environ., 112, 697707, 2008.

Finarelli M. G.: GLOBE: A Worldwide Environmental Science and Education Partnership, J. Sci. Edu. Technol., 7, 77-84, 1998.

Gerasopoulos, E., Koulouri, E., Kalivitis, N., Kouvarakis, G., Saarikoski, S., Mäkelä, T., Hillamo, R., and Mihalopoulos, N.: Size-segregated mass distributions of aerosols over Eastern Mediterranean: seasonal variability and comparison with AERONET columnar size-distributions, Atmos. Chem. Phys., 7, 
2551-2561, doi:10.5194/acp-7-2551-2007, 2007.

Giles, D. M., Holben, B. N., Eck, T. F., Sinyuk, A., Smirnov, A., Slutsker, I., Dickerson, R. R., Thompson, A. M., and Schafer, J. S.: An analysis of AERONET aerosol absorption properties and classifications representative of aerosol source regions, J. Geophys. Res., 117, D17203, doi:10.1029/2012JD018127, 2012.

Ginoux, P., Chin, M., Tegen, I., Prospero, J. M., Holben, B., Dubovik, O., and Lin, S.: Sources and distributions of dust aerosols simulated with the GOCART model, J. Geophys. Res., 106, 20255-20273, doi:10.1029/2000JD000053, 2001.

Gross, J. and Barring. L.: Wind erosion in Europe: where and when, in: Wind Erosion on Agricultural Land in Europe (Ed. A. Warren). European Commission, Directorate-General for Research, Office for Official Publications of the European Communities, Luxemburg, 13-28, 2003.

Gu, X. F., Wang, S. P., Fang, L., Yu, T., and Gao, J.: Sensitivity study on polarized aerosol retrievals of PARASOL in Beijing and Kanpur, Atmos. Meas. Tech. Discuss., 4, 5773-5806, doi:10.5194/amtd-4-5773-2011, 2011.

Hinz, T. and Funk, R.: Particle Emissions of soils induced by agricultural field operations, DustConf International Conference, Maastricht,Netherlands, 23-24 April 2007, 10 pp., 2007.

Holben, B. N., Eck, T. F., Slutsker, I., Tanré, D., Buis, J. P., Setzer, A., Vermote, E., Reagan, J. A., Kaufman, Y. J., Nakajima, T., Lavenu, F., Jankowiak, I., and Smirnov, A.: AERONET - a federated instrument network and data archive for aerosol characterization, Remote Sens. Environ., 66, 1-16, 1998.

IPCC Climate Change 2007: The Physical Science Basis, Contribution of Working Group I to the Fourth Assessment Report of the Intergovernmental Panel on Climate Change, edited by: Solomon, S., Qin, D., Manning, M., Chen, Z., Marquis, M., Averyt, K. B., Tignor, M., and Miller, H. L., Cambridge University Press, Cambridge, UK and New York, NY, USA, 2007.

Israelevich, P., Ganor, E., Alpert, P., Kishcha, P., and Stupp, A.: Predominant transport paths of Saharan dust over the Mediterranean Sea to Europe, J. Geophys. Res., 117, D02205, doi:10.1029/2011JD016482, 2012.

Jaeglé, L., Quinn, P. K., Bates, T. S., Alexander, B., and Lin, J.-T.: Global distribution of sea salt aerosols: new constraints from in situ and remote sensing observations, Atmos. Chem. Phys., 11, 3137-3157, doi:10.5194/acp-11-3137-2011, 2011.

Jaroslawski, J., and Pietruczuk, A.: On the origin of seasonal variation of aerosol optical thickness in UV range over Belsk, Poland, Acta Geophys., 58, 1134-1146, doi:10.2478/s11600-010-00194, 2010.

Kalivitis, N., Gerasopoulos, E., Vrekoussis, M., Kouvarakis, G., Kubilay, N., Hatzianastassiou, N., Vardavas, I., and Mihalopoulos, N.: Dust transport over the eastern Mediterranean derived from Total Ozone Mapping Spectrometer, Aerosol Robotic Network, and surface measurements, J. Geophys. Res., 112, D03202, doi:10.1029/2006JD007510, 2007.

Kaufman, Y. J., Tanré, D., and Boucher, O.: A satellite view of aerosols in the climate system, Nature, 419, 215-223, 2002.

King, M. D., Kaufman, Y. J., Tanré, D., and Nakajima T.: Remote sensing of tropospheric aerosols from space: past, present, and future, B. Am. Meteorol. Soc., 80, 2229-2259, 1999.

Kokhanovsky, A. A. and de Leeuw, G.: Satellite Aerosol Remote Sensing over Land, Springer-Praxis, Berlin, 398 pp., 2009.
Kokhanovsky, A. A., Deuzé, J. L., Diner, D. J., Dubovik, O., Ducos, F., Emde, C., Garay, M. J., Grainger, R. G., Heckel, A., Herman, M., Katsev, I. L., Keller, J., Levy, R., North, P. R. J., Prikhach, A. S., Rozanov, V. V., Sayer, A. M., Ota, Y., Tanré, D., Thomas, G. E., and Zege, E. P.: The inter-comparison of major satellite aerosol retrieval algorithms using simulated intensity and polarization characteristics of reflected light, Atmos. Meas. Tech., 3, 909-932, doi:10.5194/amt-3-909-2010, 2010.

Konovalov, I. B., Beekmann, M., Kuznetsova, I. N., Yurova, A., and Zvyagintsev, A. M.: Atmospheric impacts of the 2010 Russian wildfires: integrating modelling and measurements of an extreme air pollution episode in the Moscow region, Atmos. Chem. Phys., 11, 10031-10056, doi:10.5194/acp-11-10031-2011, 2011.

Korontzi, S., McCarty, J., Loboda, T., Kumar, S., and Justice, C.: Global distribution of agricultural fires in croplands from 3 years of Moderate Resolution Imaging Spectroradiometer (MODIS) data, Global Biogeochem. Cy., 20, GB2021, doi:10.1029/2005GB002529, 2006.

Lee, K. H., Li, Z., Kim, Y. J., and Kokhanovsky, A.: Aerosol monitoring from satellite observations: a history of three decades, Atmospheric and Biological Environmental Monitoring, edited by: Kim, Y. J., Platt, U., Gu, M. B., and Iwahashi, H., Springer, 1338, doi:10.1007/978-1-4020-9674-7, 2009.

Li, Z., Zhao, X., Kahn, R., Mishchenko, M., Remer, L., Lee, K.-H., Wang, M., Laszlo, I., Nakajima, T., and Maring, H.: Uncertainties in satellite remote sensing of aerosols and impact on monitoring its long-term trend: a review and perspective, Ann. Geophys., 27, 2755-2770, doi:10.5194/angeo-27-2755-2009, 2009.

Lund Myhre, C., Toledano, C., Myhre, G., Stebel, K., Yttri, K. E., Aaltonen, V., Johnsrud, M., Frioud, M., Cachorro, V., de Frutos, A., Lihavainen, H., Campbell, J. R., Chaikovsky, A. P., Shiobara, M., Welton, E. J., and Tørseth, K.: Regional aerosol optical properties and radiative impact of the extreme smoke event in the European Arctic in spring 2006, Atmos. Chem. Phys., 7, 58995915, doi:10.5194/acp-7-5899-2007, 2007.

Manders, A. M. M., Schap, M., Querol, X., Albert, M. F., Vercauteren, J., Kuhlbusch, T. A. J., and Hoogerbrugge, R.: Sea salt concentrations across the European continent, Atmos. Environ., 44, 2434-2442, doi:10.1016/j.atmosenv.2010.03.028, 2010.

Mishchenko, M. I., Cairns, B., Hansen, J. E., Travis, L. D., Burg, R., Kaufman, Y. J., Martins, J. V., and Shettle, E. P.: Monitoring of aerosol forcing of climate from space: analysis of measurement requirements, J. Quant. Spectosc. Ra., 88, 149-161, doi:10.1016/j.jqsrt.2004.03.030, 2004.

Mishchenko, M. I., Geogdzhayev, I. V., Cairns, B., Carlson, B. E., Chowdhary, J., Lacis, A. A., Liu, L., Rossow, W. B., and Travis, L. D.: Past, present, and future of global aerosol climatologies derived from satellite observations: a perspective, J. Quant. Spectrosc. Ra., 106, 325-347, doi:10.1016/j.jqsrt.2007.01.007, 2007.

Mishchenko, M. I., Liu, L., Geogdzhayev, I. V., Travis, L. D., Cairns, B., and Lacis, A. A.: Toward unified satellite climatology of aerosol properties. 3. MODIS versus MISR versus AERONET, J. Quant. Spectrosc. Ra., 111, 540-552, 2010.

Nadal, F. and Bréon, F.-M.: Parameterization of surface polarized reflectance derived from POLDER spaceborne measurements, IEEE T. Geosci. Remote, 37, 1709-1718, 1999.

Novikova A. V.: Assessment of the effect of aerial transport of salts on solonetzic process in the Black Sea region, Eurasian Soil 
Science, 42(12), 1325-1334, doi:10.1134/S1064229309120023, 2009.

Papayannis, A., Balis, D., Amiridis, V., Chourdakis, G., Tsaknakis, G., Zerefos, C., Castanho, A. D. A., Nickovic, S., Kazadzis, S., and Grabowski, J.: Measurements of Saharan dust aerosols over the Eastern Mediterranean using elastic backscatter-Raman lidar, spectrophotometric and satellite observations in the frame of the EARLINET project, Atmos. Chem. Phys., 5, 2065-2079, doi:10.5194/acp-5-2065-2005, 2005.

Papayannis, A., Amiridis, V., Mona, L., Tsaknakis, G., , Balis, D., Bösenberg, J., Chaikovski, A., De Tomasi F., Grigorov, I., Mattis, I., Mitev, V., Müller, D., Nickovic, S., Pérez, C., Pietruczuk, A., Pisani, G., Ravetta, F., Rizi, V., Sicard, M., Trickl, T., Wiegner, M., Gerding, M., Mamouri, R. E., D’Amico, G., and Pappalardo, G.: Systematic lidar observations of Saharan dust over Europe in the frame of EARLINET (2000-2002), J. Geophys. Res., 113, D10204, doi:10.1029/2007JD009028, 2008.

Pietruczuk, A. and Chaikovsky, A.: Variability of aerosol properties during the 2007-2010 spring seasons over central Europe, Acta Geophys., 60, 1338-1358, doi:10.2478/s11600-012-00179, 2012.

Remer, L. A., Kaufman, Y. J., Holben, B. N., Thompson, A. M., and McNamara, D.: Biomass burning aerosol size distribution and modeled optical properties, J. Geophys. Res.-Atmos., 103, 31879-31891, doi:10.1029/98JD00271, 1998.

Schuster, G. L., Vaughan, M., MacDonnell, D., Su, W., Winker, D., Dubovik, O., Lapyonok, T., and Trepte, C.: Comparison of CALIPSO aerosol optical depth retrievals to AERONET measurements, and a climatology for the lidar ratio of dust, Atmos. Chem. Phys., 12, 7431-7452, doi:10.5194/acp-12-7431-2012, 2012.

Sciare, J., Oikonomou, K., Favez, O., Liakakou, E., Markaki, Z., Cachier, H., and Mihalopoulos, N.: Long-term measurements of carbonaceous aerosols in the Eastern Mediterranean: evidence of long-range transport of biomass burning, Atmos. Chem. Phys., 8, 5551-5563, doi:10.5194/acp-8-5551-2008, 2008.

Seinfeld, J. H. and Pandis, S. N.: Atmospheric Chemistry and Physics: From Air Pollution to Climate Change, 2nd Edn., John Wiley and Sons Inc., Hoboken, New Jersey, USA, 1190 pp., 2006.

Smirnov, A., Holben, B. N., Eck, T. F., Dubovik, O., and Slutsker, I.: Cloud-screening and quality control algorithms for the AERONET database, Remote Sens. Environ., 73, 337-349, doi:10.1016/S0034-4257(00)00109-7, 2000.
Sterk, G. and Goossens D.: Emissions of soil dust and related problems in Europe: an overview, DustConf International Conference, Maastricht, the Netherlands, 23-24 April 2007, 12 pp., 2007.

Stohl, A., Berg, T., Burkhart, J. F., Fjǽraa, A. M., Forster, C., Herber, A., Hov, Ø., Lunder, C., McMillan, W. W., Oltmans, S., Shiobara, M., Simpson, D., Solberg, S., Stebel, K., Ström, J., Tørseth, K., Treffeisen, R., Virkkunen, K., and Yttri, K. E.: Arctic smoke - record high air pollution levels in the European Arctic due to agricultural fires in Eastern Europe in spring 2006, Atmos. Chem. Phys., 7, 511-534, doi:10.5194/acp-7-511-2007, 2007.

Su, X., Goloub, P., Chiapello, I., Chen, H., Ducos, F., and Li, Z.: Aerosol variability over East Asia as seen by POLDER space-borne sensors, J. Geophys. Res., 115, D24215, doi:10.1029/2010JD014286, 2010.

Takamura, T., Nakajima, T. and SKYNET community group: Overview of SKYNET and its activities, Opt. Pur. Apl., 37, 3303-3303, 2004.

Tanré, D., Bréon, F. M., Deuzé, J. L., Dubovik, O., Ducos, F., François, P., Goloub, P., Herman, M., Lifermann, A., and Waquet, F.: Remote sensing of aerosols by using polarized, directional and spectral measurements within the A-Train: the PARASOL mission, Atmos. Meas. Tech., 4, 1383-1395, doi:10.5194/amt-4-1383-2011, 2011.

Welton, E. J., Campbell, J. R., Berkoff, T. A., Valencia, S., Spinhirne, J. D., Holben, B., Tsay, S.-C., and Schmid, B.: The NASA Micro-Pulse Lidar Network (MPLNET): an overview and recent results, Opt. Pur. y Apl., 39, 67-74, 2006.

Witte, J. C., Douglass, A. R., da Silva, A., Torres, O., Levy, R., and Duncan, B. N.: NASA A-Train and Terra observations of the 2010 Russian wildfires, Atmos. Chem. Phys., 11, 9287-9301, doi:10.5194/acp-11-9287-2011, 2011.

Yoon, J., von Hoyningen-Huene, W., Kokhanovsky, A. A., Vountas, M., and Burrows, J. P.: Trend analysis of aerosol optical thickness and Ångström exponent derived from the global AERONET spectral observations, Atmos. Meas. Tech., 5, 12711299, doi:10.5194/amt-5-1271-2012, 2012. 